\title{
Lingvistický „obrat“ Vladimíra Hurbana Vladimírova Juliana Beňová
}

\author{
BEŇOVÁ, J.: Linguistic “Turn” of Vladimír Hurban Vladimírov \\ SLOVENSKÁ LITERATÚRA, vol. 69, 2022, no. 1, pp. 55-66 \\ DOI: https://doi.org/10.31577/slovlit.2022.69.1.5 \\ ORCID ID: https://orcid.org/0000-0002-2764-2375
}

\begin{abstract}
Key words: linguistic works of
VHV, language planning, Stara

Pazova, language courses, Josip

Andrić: Slovačka slovnica, Slovak

orthography reform
\end{abstract}

Taking the work of Vladimír Hurban Vladimírov (pseudonym VHV, 1884-1950) as its prism, the article aims at providing an insight into the state of the language and the issue of language politics in the interwar period in the Slovak linguistic enclave in Vojvodina, Serbia. The article analyses the linguistic work of VHV and addresses the topic of language planning. VHV, in his attempts at strengthening the knowledge of their mother tongue among Slovaks in Serbia, took an active part in the forming of the modern Slovak language. He published linguistic essays in local periodicals and developed language courses for the locals. He taught Slovak in two basic courses - in 1925 and 1943 - in Stara Pazova. The students of his second course used Slovačka slovnica (1942) - a grammar book written by the Croatian Slovakophile Josip Andrić (1894-1964). The level of the knowledge of the language among the locals and the lack of specialised and normative publications prompted VHV to explain phenomena pertaining to Slovak orthography, morphology, lexicology, etymology and dialectology. He advocated for an etymological orthography and was of the opinion that orthography should only reflect the standard and codified variation of the language. 


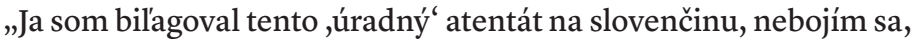
ked'sa o tom dozvedia i vinníci!“

(Vladimír Hurban Vladimírov)

„Reč je živý výkon ducha pomocou orgánov človeka, vyviňuje sa a zdokonaluje sa v ústach každého jednotlivca, je prirodzená a individuálna - ale čím ju chceme zaznačit', nemôžeme upotrebit' také individuálne pravidlo: píš, ako hovoríš, lež k tomu je potrebné mocnejšie a všeobecnejšie pravidlo, pravidlo založené na historickom vývine reči, teda na etymologickom princípe."

(Vladimír Hurban Vladimírov)

V najrozličnejších funkciách a podobách sa slovenčina ako základný poznávací a komunikačný prostriedok použiva nielen na Slovensku, ale prekračuje zemepisné hranice viacerými smermi do Európy i mimo nej a do rozrastajúcich sa slovenských diaspór a enkláv, kde sa prejavuje v rozmanitých formách, varietach a variantoch. V minoritnom spoločenstve žijúcom mimo hraníc materského národa sa nepochybne objavujú špecifiká spojené s prostredím, v ktorých si jazykové komunity udržiavajú svoj jazyk. V slovenčine používanej mimo územia Slovenska sú úplne prirodzené stopy podmienok, v ktorých sa formovala a uplatňovala. Variabilné manifestácie jazyka v interpersonálnej a verejnej komunikácii v slovenských enklávach tak možno v istom zmysle chápat' ako špecifické prejavy zvukového, morfologického a lexikálneho bohatstva slovenčiny. Predmetom môjho výskumného záujmu je jazyk Slovákov žijúcich vo Vojvodine, v troch oblastiach (Báčka, Banát, Sriem), kam už koncom 18. storočia prišli prvé rodiny Slovákov, ktoré opustili svoju pôvodnú vlast'. V rámci niekol'kých migračných vín sa postupne usadili v najjužnejších častiach Uhorska, aby tam zveladili miesta spustošené Osmanmi. Ako pristahovalci si uvedomovali potrebu zachovania homogénnosti $\mathrm{v}$ rovine rodinných tradícií, spoločenských a morálnych hodnôt, ale najmä v oblasti jazyka a kultúry. Odchádzajúc z rozličných slovenských stolíc, do nového domova si niesli nielen prostriedky pre materiálne zabezpečenie, ale rovnako pre duchovné a kultúrne bytie. Tak sa do dnešnej Vojvodiny dostali tiež učitelia a kňazi, v novom prostredí zabezpečujúci spoločenský a duchovný život a takisto vyučovanie v materinskom slovenskom jazyku, ktorý pestovali a kultivovali.

Vo vojvodinskom mestečku Stará Pazova nastúpil v roku 1875 na faru mladý, sotva dvadsat'pätročný kňaz Vladimír Hurban (1850 - 1914), syn známeho národovca Jozefa Miloslava Hurbana. Horlivý patriot, organizátor spoločenského života, spisovatel' a publicista slúžil na fare takmer štyridsat' rokov. Podporoval hospodársky, komunálny i kultúrny rozvoj mestečka, založil Slovenskú pospolitú čitáreň a Slovenskú evanjelickú vzájomnú pomocnicu. Vela energie vkladal do rozvoja divadelného umenia v Starej Pazove, kde pod jeho vedením uviedli veselohru Testiná do domu, spokojnost'z domu (2. februára 1903), pričom išlo o vôbec prvé slovenské predstavenie pazovských ochotníkov. Okrem toho aktívne sledoval prácu Srbského národného divadla v Novom Sade, až sa v roku 1884 stal členom jeho organizačného výboru. Spolu s manželkou Augustou, rodenou Štúrovou, dcérou Jána Štúra (brata L'udovíta Štúra), podporovali národné ciele, literatúru a kultúru a viedli k tomu aj svoje dve deti, dcéru L'udmilu (1878 
-1969) a syna Vladimíra (1884-1950). Spojenie štúrovskej a hurbanovskej rodinnej línie viedlo L'udmilu Hurbanovú k aktívnej práci v oblasti národnej kultúry a ochotníckeho divadla. Po štúdiách na dievčenskom lýceu v Záhrebe sa vrátila na hurbanovskú faru, kde sa stala spolu s bratom Vladimírom oporou kultúrneho a spoločenského života v Starej Pazove. ${ }^{1}$

Mladší Hurbanov vnuk Vladimír Konštantín Hurban, syn Vladimíra Hurbana a Augusty Štúrovej, je slovenskej kultúrnej verejnosti známy pod umeleckým menom Vladimír Hurban Vladimírov (uverejňujúci aj pod pseudonymom VHV) ako úspešný dramatik, literát a publicista ${ }^{2}$ (Vladimír Hurban Vladimírov... 1986-1987, Pašteka 1990, Babiak 2011, Hučková 2016, Cupanová 2021a, 2021b). Málo sa však hovorí o jeho lingvistickom diele, praktickej činnosti v oblasti jazykového plánovania a skúmaní staropazovského nárečia. Jazyku vojvodinských Slovákov začal venovat' značnú pozornost' $\mathrm{v}$ dvadsiatych rokoch 20 . storočia a v teoretickom výskume a praktických jazykových kurzoch bol aktívny d'alších dvadsat' rokov. „Lingvistický obrat" VHV bol pravdepodobne spôsobený oficiálnymi a verejne deklarovanými aktivitami v oblasti jazykovej politiky v novovzniknutom Československu, kedy sa na prvé priečky pomyselného rebríčka jazykového plánovania dostávala otázka podoby modernej slovenčiny. ${ }^{3} \mathrm{~S}$ rozmanitými aktivitami zameranými na modifikáciu i stabilizáciu jazykového správania vojvodinského rečového spoločenstva, teda s plánovaním jazykovej „situácie“ spisovného jazyka, začal VHV najmä z praktických dôvodov. V každodennom styku s obyvatel'mi Starej Pazovy a v kontakte s používatel'mi slovenčiny reflektoval, že tamojšie slovenské etnikum neovláda slovenskú ortografiu a gramatiku, čo on považoval

1 Do domu Hurbanovcov často prichádzali priatelia, spisovatelia, osvetoví pracovníci i divadelníci a L'udmila pripravovala a iniciovala spoločenské stretnutia. Zdokonal'ovala sa v jazykoch, o veciach národných i súkromných viedla početnú korešpondenciu s Ludmilou Podhradskou, Karolom a Jánom Štúrom, Jozefom Maliakom a organizovala divadelný život v Starej Pazove a jej okolí. Bola zakladajúcou členkou a zároveň predsedníčkou Ústredného spolku československých žien v Královstve Srbov, Chorvátov a Slovincov. Písala krátke prózy, bájky a jednoaktovky, zdramatizovala poviedku Rysavá jalovica, je autorkou viacerých rozprávok. Správy o divadelných predstaveniach posielala do slovenských novín a časopisov.

2 Po slávnych predkoch zdedil VHV umelecký i organizačný talent. Po štúdiách na gymnáziu v Záhrebe a teológii vo Viedni a v Bratislave pôsobil ako učitel', kaplán a neskôr evanjelický farár v Starej Pazove, kde sa popri kňazských povinnostiach venoval najmä literárnej a publicistickej činnosti. Písal najmä divadelné hry, teoretické práce o divadle a literatúre. Bol novátorom v oblasti témy a experimentoval s kompozíciou. Jeho drámy vykazujú znaky profesionálnych divadelných kultúr európskych vel'komiest a moderných dramatických prúdov (symbolizmu a expresionizmu). V rozsiahlom dramatickom diele VHV sú hry realistické, historické, symbolistické i expresionistické, dokonca aj libretá opier. VHV patrí k priekopníkom v tvorbe filmového scenára.

3 Najmä v období konštituovania moderných národných štátov možno sledovat viaceré iniciatívy v oblasti jazykovej politiky. Nebolo tomu inak ani po vzniku samostatnej Československej republiky, ked' ústava nového štátu (1920) zákonom č. $122 \mathrm{Zb}$.v $\$ 1$ zakotvila, že štátnym, oficiálnym jazykom republiky je jazyk československý, ktorý sa podl'a $\$ 4$ používa na území Slovenska „spravidla po slovensky“. Ustanovené dvojaké znenie jazyka - české a slovenské - vychádzalo z jazykovej reality. Tvorcovia zákona si totiž dobre uvedomovali, že jazyk československý neexistuje a takéto rozhodnutie malo oporu najmä v politických potrebách formujúceho sa štátu. Nová podoba slovenčiny sa tak formovala na pozadí politickej doktríny jednotného československého národa a jazyka, pričom sčasti bola podporovaná aj teóriou o neschopnosti spisovnej slovenčiny stat' sa moderným jazykom vedy a civilizácie. Takéto tvrdenia vyvolávali ostrú odbornú i spoločenskú kritiku a najmä medzi jazykovedcami viedli k dlhotrvajúcim polemikám a sporom. Použivanie jazykov síce zákon priamo vymedzoval, dve jazykové „podoby“ však spôsobovali v praxi mnohé nedorozumenia a problémy, ktoré sa čoskoro prejavili najmä v oblasti normovania gramatiky a slovníka spisovného jazyka. Predmetom rozsiahlych diskusií, útokov i obrán sa tak stala aj kodifikovaná podoba (novej) slovenčiny. 
za neprípustné: ,Je to najväčšia neúcta, ak nie zločin proti svojej materčine, môct' a nechciet' ju správne naučit' sa písat"“ (Hurban 2014: 15). Nepochybne aj status evanjelického kňaza a učitela, ako i úcta a rešpekt, ktoré mal medzi obyvatel'mi mestečka so slovenskou societou, ho podporovali v úvahách, aby Slovákov vzdelával v slovenskom jazyku, a to prostredníctvom praktických jazykových kurzov a teoretických lingvistických prác.

Prvé aktivity VHV v oblasti ozrejmovania a vysvetl'ovania lingvistických javov zo slovenského pravopisu, hláskoslovia a morfológie sa viažu na jazykový kurz organizovaný pre vybranú skupinu obyvatel'ov Starej Pazovy. Podl'a výzvy - akéhosi otvoreného listu z roku $1925^{4}$ - sa na vzdelávací kurz slovenčiny mohli prihlásit iba muži, pre ktorých bolo ovládanie slovenčiny potrebné najmä pri výkone povolania. Praktický kurz slovenského pravopisu ponúkaný a vedený VHV mal účastníkom zabezpečit, že po absolvovaní piatich vyučovacích hodín budú „vediet' slovensky písat"“. ${ }^{5} \mathrm{~V}$ emotívne ladenom oznámení vychádzal VHV z kňazských skúseností a využíval i literárny talent, ked' pozvanie na vzdelávanie v slovenskom pravopise formuloval ako verejnú výzvu adresovanú miestnej „pánskej“ spoločnosti, aby získal čo najvyšší počet účastníkov a najmä, aby svojím oznámením zaujal:

„Ctení pánovia, tej jeseni chcem poučovat' slovenský pravopis. Ak myslíte, že Slovák nemusí a nemá vediet' po slovensky písat', ak myslíte, že Slovák tu v SHS ${ }^{6}$ nesmie vediet pravopis slovenský, ak myslíte, že je správne písanie svojej materinskej reči tu u nás nepotrebné - tak vás nečakám. Ale ak myslíte, že je to svätá naša povinnost' vediet slovensky písat' [...] ak ste len trošku - troštičku hrdí na to, že ste Slovák - tak majte tol'ko hrdosti - ale aj úcty k tomu jazyku a naučte sa ho správne písat'. Ja vás volám!“7

Takto koncipovaný stimulačný a provokujúci apel vykazuje značné prvky angažovanosti, irónie i sarkazmu a nezaprel ani dramatický potenciál VHV. Výzva adresovaná súdobému pazovskému obyvatel'stvu nezostala zrejme nepovšimnutá, hoci explicitný dôkaz o tom, že sa kurzy uskutočnili, nemáme. Akýmsi potvrdením o realizovaní kurzov však môže byt' poznámka VHV k článku z roku 1927 uverejnenom v časopise Národná jednota pod názvom Sedem hodín o slovenskom pravopise, teda dva roky po ponúkanom kurze, v ktorej sa VHV odvoláva na uskutočnenie kurzov slovenského jazyka: „Tieto prednášky o pravopise držiaval som pred asi dvoma rokmi v úzkom kruhu našich Slovákov, ktorí z povolania súc pisármi, najviac prichádzajú do položenia niečo písat' a preto ich povinnostou je i slovensky vediet písat'. Ak to našim gazdom a iným pánom, nenačim', pre každého

4 Archív Slovenskej evanjelickej a. v. cirkvi v Starej Pazove, inventárne číslo 292.

5 Archív Slovenskej evanjelickej a. v. cirkvi v Starej Pazove, inventárne číslo 292.

6 SHS - autorom použitá skratka pre názov štátu; oficiálny názov štátu od 15. júla 1920 bol Královstvo Srbov, Chorvátov a Slovincov (Kraljevina Srba, Hrvata i Slovenaca) - odtial' iniciálová skratka SHS pre vyjadrenie názvu krajiny.

7 V otvorenom „liste“ z 22. septembra 1925 informuje VHV obyvatel'ov Starej Pazovy o tom, že plánuje otvorit' pät'týždňový kurz slovenského pravopisu. Vyučovanie malo prebiehat' každý pondelok v podvečerných hodinách v priestoroch Slovenskej pospolitej čitárne v Starej Pazove. Rukou písaný dokument (možno ide o letáčik - agitačné tlačivo) sa nachádza v Hurbanovej pozostalosti. Archív Slovenskej evanjelickej a. v. cirkvi v Starej Pazove, inventárne číslo 292. 
človeka potrebné je, ktorý si namýšla byt' Slovákom, aby vedel i slovensky písat"“ (Hurban 1927: 2).

Aj samotná kompozícia textu Sedem hodín o slovenskom pravopise celkom jasne potvrdzuje, že VHV prednášky medzi Slovákmi realizoval. Každý odsek sa začína poradovým číslom príslušnej vyučovacej hodiny („Prvá hodina“, „,Druhá hodina“ až po „Siedma hodina“), pričom niektoré sú ukončené didaktickými poznámkami v zátvorke: „Diktát, srovnávanie a opravy. [...] Cvičby v písaní [...] Opätovat' predošlé“ (Hurban 2014: 18-21). Jednotlivé vyučovacie bloky vystaval VHV koncízne a heslovite. Na prvom stretnutí podal stručný prehl'ad vývinu slovenčiny od staroslovienčiny po súdobé pravidlá, ktoré „ustálil Samo Czambel“ (Hurban 2014: 17); na druhej a tretej hodine sa venoval zvukovej sústave slovenčiny, podal klasifikáciu samohlások, spoluhlások a dvojhlások, priblížil podstatu rytmického zákona a upozornil na problematické ortoepické javy pri dvojhláskach; štvrtá hodina bola zameraná na mäkké konsonanty a ich ortoepiu a v piatej, podla VHV „najtažšej hodine“ (Hurban 2014: 19), sa sústredil na vysvetlenie rozdielov medzi používaním „i“ a „y“, pričom práve existenciu grafémy „y“ považoval za „bohatstvo slovenčiny“, pretože práve v ,tomto ypsilone sa ukazuje, že totiž máme pre jeden hlas i štyri znaky“ (Hurban 2014:19). V tejto súvislosti možno dodat', že k problematike používania „y“ sa VHV vracal opakovane aj v iných svojich lingvistických príspevkoch, pričom na rozdiel od tých, ktorí navrhovali vylúčenie „y“ zo slovenčiny, neochvejne obhajoval jeho význam a potrebu. V šiestej vyučovacej hodine sa zameral na pravopisné princípy uplatňované pri písaní hlások ä, ô, ĺ, ŕ, o ktorých hovoril, že sú to „zvláštne slovenské hlásky“ a upozorňoval na dôležitost' ich správnej výslovnosti (Hurban 2014: 21). Poslednú siedmu hodinu venoval najvypuklejším problémom v ortografii i ortoepii predložiek a prefixov, ako aj problematike správnej interpunkcie. Prednášky koncipoval tak, aby upozornil na najzávažnejšie chyby v slovenčine, s ktorými sa u používatel'ov najčastejšie stretával, na tie, ktoré boli najmä vo verejných prejavoch najvypuklejšie a neustále sa opakovali. Publikovanie prednášok o slovenskom pravopise len potvrdzuje úsilie VHV vzdelávat' domáce obyvatel'stvo v čo najširšom meradle a na rôznych platformách. Dva roky po realizovaní ,jazykového kurzu“ považoval za potrebné zverejnit jeho obsah a apelovat' na používatel'ov slovenčiny, aby si materinský jazyk vážili a nezneuctovali ho tým, že neovládajú ortoepické a ortografické pravidlá. Vo svojich výzvach zašiel VHV až k otázkam identifikácie sa so slovenským národom a problematike jazykovej segregácie z komunity, odvolávajúc sa na solidaritu a reciprocitu tých používatel'ov, ktorí majú slovenčinu v úcte a rešpektujú jej zákonitosti vo verejnom jazykovom prejave: „Stvorme ligu pre pravopis a kto nevie a nechce sa učit' ale predsa chce písat' slovensky, toho bojkotujme ako najväčšieho hanobitel'a slovenčiny! Tomu znemožníme, aby sa vystatoval ako Slovák, ked' tak zneuctuje slovenčinu! S takým ani sa neshovárajme po slovensky, lebo nie je hodný pol slova počut z našej sladkej materčiny. Slováci-za slovenský pravopis!“" (Hurban 2014: 22)

Ďalší kurz slovenského jazyka zorganizoval VHV pre obyvatel'ov Starej Pazovy takmer o dvadsat' rokov neskôr, ked' ho k tejto aktivite priam vyzvali miestni úradníci. Existenciu d'alších „externých“ hodín slovenčiny pre verejnost' dokladá list, ktorý VHV adresoval úradníkovi Jánovi Klátikovi v posledný decembrový deň roku 1942. Reagoval v ňom na Klátikov dopyt po jazykovom vzdelávaní 
a slúbil, že s novým rokom sa začne aj nové vyučovanie rozdelené do troch skupín: 1. Učenie slovenského pravopisu; 2. Prehl'ad slovenskej spisby; 3. Niečo z dejepisu a zemepisu Slovenska (Hurban 2014: 107). Kurz s názvom Náukobeh slovenčiny pripravil VHV pre miestnych úradníkov s ciel'om naučit' ich „materčinu správne písat', lebo napísané slovo zostáva a ked' je zle napísané od človeka, ktorý sa bije do pŕs, že je Slovák, tak je to i vel'ká hanba preňho" (Hurban 2014: 107). Z d'alšej korešpondencie medzi Klátikom a VHV vyplýva, že do náukobehu sa prihlásilo trinást' respondentov ${ }^{8}$ a prvé stretnutie naplánovali na 12. februára 1943 v Slovenskom národnom dome v Starej Pazove. Pre nový kurz slovenčiny sa VHV nadchol nielen vd'aka tomu, že ho budúci respondenti oslovili, uvedomujúc si potrebu doplnkového vzdelávania v oblasti jazyka a kultúry, ale aj vd'aka skutočnosti, že na kurze sa mohol opriet' o aktuálnu knižnú novinku, ktorá mala zabezpečit úspešnost', no najmä adekvátnu odbornost' a relevantnost' kurzov slovenského jazyka. Novou učebnicou bola chorvátska publikácia Slovačka slovnica. Slovnica slovačkog jezika, ktorej autorom bol Josip Andrić. ${ }^{9}$ Slovenskí čitatelia v Starej Pazove sa k nej dostali už začiatkom roku 1943, teda ihned' po jej vydaní v Záhrebe. Za rýchlou distribúciou knihy nepochybne stáli čulé kontakty VHV s predstavitel'mi Slovenskej republiky (1939-1945) v Nezávislom chorvátskom štáte (NDH), ${ }^{10}$ ako aj dobré vzt'ahy, ktoré mal VHV s predstavitelmi Slovákov a slovenskej menšiny v NDH. ${ }^{11}$ V komplikovanom období druhej svetovej vojny sa tak vd'aka aktivitám VHV dostala medzi vojvodinských Slovákov odborná publikácia opisujúca slovenskú fonetiku, morfológiu a sčasti i syntax v chorvátčine, v jazyku, ktorí Slováci žijúci vo Vojvodine pomerne slušne ovládali. Vydanie slovenskej gramatiky prijal VHV s nesmiernym nadšením, pretože kniha sa mu hodila ako učebná pomôcka pre práve pripravovaný kurz:

„Každé učenie potrebuje okrem pilných a snaživých poslucháčov a vytrvalých učitel'ov i príručnú učebnú knihu, ktorú by mal každý navštevovatel' Náukobehu a tak sledoval prednášky, porovnával prednášané s tlačeným textom a mal vždy pri ruke základ dl'a ktorého by sa potom doma d'alej vzdelával a poučoval. Takejto praktickej knihy,

8 Z podpísaného prihlasovacieho hárku poznáme mená účastníkov kurzu. Počet prihlásených VHV vtipne komentoval slovami: „Trinásti sú tam podpísaní: teda 13 - Pán Boh pri nás, ako hovorí slovenské porekadlo." Rukopis troch listov, Archív Slovenskej evanjelickej a. v. cirkvi v Starej Pazove, prírastkové číslo UDR 19421231/4882.

9 Dr. Josip Andrić (1894 - 1967) bol chorvátsky filológ, právnik a muzikológ, v rokoch 1921 - 1946 pôsobil ako šéfredaktor v katolíckom vydavatel'stve Spolok sv. Hieronyma. Jeho gramatika slovenského jazyka Slovačka slovnica. Slovnica slovačkog jezika vyšla koncom roka 1942 ako prvá slovenská gramatika vydaná mimo územia Slovenska. Publikácia sa dočkala dvoch reprintov: prvá pretlač vyšla v Záhrebe v roku 2003 a druhá rovnako v Záhrebe v roku 2013. Druhý reprint vznikol pod redakciou Josipa Mosera a Zvonka Benčića. Obsahuje aj štúdiu venovanú životu a dielu J. Andrića (autor J. Moser) a odborné štúdie zaoberajúce sa chorvátskym jazykom (autor Stjepan Babić) a slovenským jazykom (autorka Dubravka Sesar) v Andrićovej gramatike.

10 Od apríla 1941 bola Stará Pazova súčastou Nezávislého štátu Chorvátsko (Nezavisna Država Hrvatska - NDH) a úradnou rečou v Starej Pazove sa stala chorvátčina. NDH bol vyhlásený 10. apríla 1941 a vznikol na území bývalej Chorvátskej bánoviny, Bosny a Hercegoviny a východnej časti Sriemu, spolu s mestom Zemun. V novom štáte žilo podla štatistických údajov 44267 Slovákov a Čechov.

11 Vzájomné kontakty medzi VHV a mimoriadnym vyslancom v NDH Jozefom Ciekerom, ktoré sa začali ešte počas Ciekerovho pôsobenia ako charge d'affaires v Belehrade, rozvijal Hurban aj v komplikovanom období existencie NDH. Bližšie o kontaktoch a spolupráci medzi slovenskou menšinou vo Vojvodine a politickými predstavitel'mi Slovenskej republiky Škorvanková 2017. 
špeciálne my Slováci v Chorvátsku sme nemali. Naše doterajšie knihy o slovenskej reči, o gramatike, o pravopise, o štylistike atd'. aká sa upotrebuje na Slovensku a na školách a v praxi, sú pre nás chorvátskych Slovákov nie len nedostižitel'né menovite v dnešné časy, ale i v mnohom nesrozumitel'né“" (Hurban 2014: 109).

Podl'a VHV sa vd'aka Andrićovi dostala k Slovákom „vzácna kniha“, ktorá za istých okolností mohla plnit úlohu učebnice slovenčiny. Zanietený a nadšený VHV v novej gramatike nevidel žiadne nedostatky, a tak ju odporúčal každému, kto sa chcel naučit' správne po slovensky písat' a hovorit' a zároveň ovládal srbský alebo chorvátsky jazyk. Andrićova gramatika sa skladá z troch kapitol: v úvodnej časti sú krátke dejiny slovenčiny, prehl'ad slovenských nárečí a porovnanie slovenčiny s inými jazykmi; druhá kapitola je venovaná hláskosloviu a tvorbe slov a v tretej, najrozsiahlejšej, opisuje autor morfologickú rovinu slovenčiny, pričom najviac pozornosti zameriava na slovné druhy a ich tvary. Primárnym ciel'om J. Andrića bolo vytvorit' „,korektnú praktickú gramatiku, ktorá predovšetkým poslúži svojmu cielu, t. j. bude prijatel'ná a zrozumitel'ná pre priemerného chorvátskeho používatel'a“ (Sesar 2013: 195). Pre pazovských frekventantov „náukobehu“ predstavovala nová gramatika jedinečnú učebnú pomôcku, ktorá podla organizátora kurzu „, l'ahkom a srozumitel'nom spôsobe vynáša všetko to, čo má každý Slovák vediet' o svojom jazyku“ (Hurban 2014: 109). Kniha tak podporovala úmysly VHV v zdokonalovaní sa v materinskom jazyku a utvrdzovaní slovenskej gramatiky a ortografie, pretože sa domnieval, že vd'aka novej učebnici bude môct' „,každý chorvátsky Slovák dobre rozumiet'a dl'a nej naučit' sa svoj drahý materinský jazyk správne hovorit'a písat"“ (Hurban 2014:110). Zachovaná korešpondencia dokumentuje, že účastníci náukobehu si odporúčanú učebnicu zabezpečili a svedomite sa pripravovali na prvé spoločné stretnutie plánované na február roku 1943. Odborné školenie dospelých v slovenskom pravopise orientoval VHV predovšetkým na úradníkov, aby okrem úradnej reči vedeli správne komunikovat' aj v materinskej reči. Úradníci sa zas radi podrobili vzdelávaniu vedenému domácim učitel'om, pretože v uznávanom evanjelickom kňazovi a literátovi videli najvyššiu jazykovú autoritu, čo bolo podporené aj predchádzajúcimi publikovanými jazykovednými prácami VHV.

Po skúsenostiach s praktickou stabilizáciou jazykového správania okolitého spoločenstva sa VHV vydal na cestu teoretického ozrejmovania slovenskej gramatiky. V periodikách vychádzajúcich vo Vojvodine publikoval v rokoch 1927 - 1940 takmer štyridsat' príspevkov venovaných slovenčine. Jazykovedne zamerané texty vznikali často ako besednice - VHV ich žánrovo označoval ako „linguistická beseda“, „beseda od VHV“ či „,besiedka pravopisná“- a krátke články. Neúnavný propagátor a obhajca spisovnej slovenčiny vytvoril pomerne rozsiahle jazykovedné dielo, ktoré súborne vyšlo v roku 2014 pod názvom Jazykovedné práce. Zostavovatel'ka publikácie Anna Marićová rozdelila jazykovedné texty VHV do troch kapitol. V prvej sú zaradené texty, ktoré VHV publikoval v rokoch 1927 - 1940 vo vojvodinských periodikách, druhú čast' publikácie tvoria odpisy zachovaných rukopisných (strojopisných) prác a v tretej kapitole je uverejnený sken rukopisu, ktorý zostavovatel'ka označila ako Slovník cudzích slov od A po Z, avšak vzhl'adom na názov sa slovník končí predčasne, prvými heslami písmena 
„T“. K slovníku neexistuje opis, nepoznáme okolnosti jeho vzniku a neprešiel ani lexikografickým skúmaním.

V časopiseckých a novinových príspevkoch sa VHV zameriaval najmä na praktické používanie jazyka. Čitatel'om približoval pravopisné zaujímavosti i výnimky, odhal'oval etymológiu slov (napríklad v besednici nazvanej Týždeň publikovanej v roku 1929 vysvetluje nielen samotnú etymológiu, ale odhaluje aj rozličné konotácie i kolokácie spojené s dňami v týždni). ${ }^{12}$ Často vysvetl'oval pôvod slovenských mien a priezvisk a pravidlá ich písania. Odborný výklad spestroval popularizačnými prvkami a umelecký duch nezaprel ani pri autorizácii textov, ked' okrem podpisovej skratky VHV, ktorú využíval najčastejšie, signoval články aj menami ako „Linguista z Tunkabonu“, „Ďrko (Pseudonym si nevyzradím ani za svet - však aj tak viete kto som) “ či „Gréckoučený Ďurko (= GEORGINOS!!)“ (Hurban 2014: 61, 36, 32). V textoch adresovaných širokej verejnosti sa VHV sústredil najmä na domácu jazykovú prax - napríklad navrhoval nový spôsob písania telegramov Morseovou abecedou v slovenčine, ${ }^{13}$ venoval sa používaniu čísloviek, zloženým slovám, otázkam interpunkcie, vysvetl'oval sémantiku biblických mien alebo upozorňoval na problematické medzijazykové homonymá (homomorfiu, homofóniu). Zaujímavé sú texty, v ktorých upriamuje pozornost' na vtedy pomerne málo rozšírenú problematiku esperanta - v esperante uvádzal slovenské piesne i výňatky z evanjelia (napríklad Evanjelium o dobrom pastierovi podáva aj s vysvetlením a analýzou gramatických javov), venuje sa tvoreniu slov v esperante pomocou sufixov a ukazovacím a opytovacím zámenám v esperante.

Dôležitú kapitolu v lingvistickom diele VHV predstavovala otázka slovenskej ortografie. Existencia a podoba slovenčiny v multilingválnom prostredí so silným nárečovým vplyvom a v koexistencii s inými jazykmi, najprv paralelne s mad'arčinou, nemčinou a d'alšími jazykmi, neskôr v koexistencii a konkurencii so srbčinou, bola podmieňovaná a formovaná špecifickými mimojazykovými okolnostami (sociálnymi, historickými a geografickými). VHV si vel'mi dobre uvedomoval, že vnútorná hranica spisovnej slovenčiny u vojvodinských Slovákov bola značne narušená a do hovoreného i písaného štandardu sa dostávali nárečový úzus a dominujúca srbčina, čo viedlo k častým chybám v slovenčine, pričom práve ortografické chyby považoval VHV za najvypuklejšie a najpočetnejšie. V rozvíjajúcej sa publicistickej sfére sa pre VHV otvorilo miesto nielen na prezentáciu vlastných jazykovedných skúmaní, ale našiel sa v nej aj priestor pre polemické texty, ktorých „obsah zahŕňal aj jazykové pozadie“ (Koruniak 2020:163), pričom

12 Ako príklad uvádzam vysvetlenie etymológie pomenovania druhého dňa v týždni: „Slovo utorok je staroslovanský výraz a znamená druhý (vtorý). Tento výraz sa len u Rusov zachoval, u Horvátov upotrebujú niekde výrazy po-vtoriti, opätovat', niečo po druhý raz konat'. Utorok je vlastne prvý deň skutočnej práce. Čistá hlava a odpočinutý človek. Nemecky volá sa Dienstag - tedy deň služby, práce. V Pazove obyčajne v utorok v jeseni sa vybavujú zabíjačky“ (Hurban 2014: 27).

13 V liste z roku 1942 adresovanom poštovému úradníkovi Gengelackému ponúka VHV systém prepisovania mäkkých spoluhlások a dlhých samohlások spôsobom zdvojeného zapisovania samohlásky či spoluhlásky, uvedomujúc si, že práve takéto „znaky za naše litery“ budú najpresnejšie vyjadrovat' dané fonémy: „Môj klúč je tento: Všetky slovenské znaky, teda: dĺžky, mäkčene, ô, takto by sa daly na telegrame, bez nových znakov označit: Jednoducho - poneváč v slovenčine niet duplých hlások (ss, cc, nn atd') - napišem na telegrafskú blanketu na tento spôsob, aby som označil, že tá duplá litera, vlastne je dížka, alebo mäkčeň, alebo ô.“ Citované z listu VHV z 2. apríla 1942, Archív Slovenskej evanjelickej a.v. cirkvi v Starej Pazove, prírastkové číslo RL19420402/4701, inventárne číslo 982. 

slovenčiny. V polemikách, ktoré vychádzali najmä v periodiku Národná jednota, obsahovo dominovali otázky reformy slovenského pravopisu a všeobecná problematika smerovania a rozvoja slovenčiny.

Medzi slovenskými kultúrnymi dejatel'mi, učitel'mi a kňazmi sa v tridsiatych rokoch 20. storočia začali objavovat' názory na potrebu radikálnych zmien v slovenskom pravopise. Na čele rezolútnych výziev smerujúcich k pravopisným zmenám stál Igor Branislav Štefánik (1873-1940), ${ }^{14}$ evanjelický kňaz, publicista a poslanec, starší brat Milana Rastislava Štefánika, ktorý predložil viaceré návrhy na reformu slovenského pravopisu a analyzoval jeho súveký stav. Vychádzajúc z empírie podal obraz o jazykovom vedomí Slovákov žijúcich vo Vojvodine a reálnej podobe ovládania pravopisu dolnozemskými Slovákmi. ${ }^{15}$ Štúdiom jazyka dospel I. B. Štefánik k presvedčeniu, že aj jazykovedci si budú musiet' uvedomit' potrebu reformy pravopisu a nepochybne budú žiadat radikálnu zmenu v pravopise, pričom prvým krokom v reforme má byt' vylúčenie „y“ zo slovenčiny. Zastával myšlienku, že slovenský pravopis musí vychádzat' zo ,živej reči národa“, a požadoval „y“ zo slovenčiny úplne odstránit: „Y ako nie je potrebný v srbskej spisbe práve tak nie je potrebný ani v našej." ${ }^{16}$ Podl'a I. B. Štefánika musia mat' Slováci taký pravopis, ktorý by si každý Slovák l'ahko osvojil. Pravopis, ktorého hlavnou zásadou je pravidlo „píš, ako hovoríš“, sa musí „priblížit reči ludu, ba dl'a možnosti, stotožnit' s ňou a nie miliony aby sa trúdily a trápily a hlavy si lámaly nad pravidlami, viac menej úmele sostavenými od lingvistov - theoretikov" ${ }^{17} \mathrm{~V}$ slovenčine už „y“ nemá miesto, z reči ludu ,dávno vykapal“, 18 a tak nie je potrebné už aj tak komplikovaný slovenský pravopis ešte viac komplikovat'.

Proti aktivitám vyzývajúcim k odstráneniu ypsilonu zo slovenčiny, ktoré sa niesli pod heslom „preč s ypsilonom“, VHV kategoricky vystúpil. Postavil sa za etymologický pravopis a tvrdil, že pravidlá musia byt' „ustálené a nemôžu sa spravovat' podl'a toho, ináč vel'mi komótneho Vukovho pravidla: píš ako hovoríš!“

14 Igor Branislav Štefánik študoval na lýceu v Bratislave, kde ako žiak Jána Kvačalu skatalogizoval knižnú zbierku bratislavskej lyceálnej knižnice. Na univerzite v Budapešti študoval právo, potom teológiu v Šoproni a Prešove a napokon v Rostocku filozofiu a psychológiu. Po ukončení štúdia bol v roku 1898 vysvätený za kňaza v Miškolci. Ako kaplán pôsobil v Sarvaši a Liptovskom Mikuláši a 4. marca 1902 bol zvolený za farára na Myjavu. Po krátkom pôsobení na Myjave odišiel do Palanky (Srbsko, Vojvodina, dnes Bačka Palanka), kde v júli 1903 prijal miesto evanjelického farára. Do roku 1920 pôsobil ako farár v Palanke, v rokoch 1920 - 1923 žil v Československu a zahraničí (zariad'oval pozostalost' po bratovi Milanovi) a od roku 1924 bol farárom v rumunskom Nadlaku. Nadlak opustil v roku 1927 a vrátil sa do Nového Sadu, kde pôsobil ako učitel'náboženstva na rôznych školách a administrátor cirkvi v Binguli. Prestal byt' politicky činný, venoval sa publicistike a organizovaniu evanjelickej cirkvi na Dolnej zemi. Od roku 1934 bol na dôchodku, venoval sa písaniu a prekladom.

15 Početné aktivity I. B. Štefánika v oblasti slovenskej jazykovedy je možné rekonštruovat' len na základe rukopisného torza pozostávajúceho z pätdesiatich dvoch rukopisných stránok. Niektoré dokumenty majú podobu esejí, publicistických príspevkov či subjektívnych reflexií, iné zas formálne vykazujú žáner súkromného listu, avšak bez adresáta. Dokumenty nie sú datované, číslované ani pomenované. Zdevastovanú Štefánikovu pozostalost' zachránil kňaz Gustáv Vladimír Babylon a po jeho smrti sa dostala do rúk rodiny Jána Gubu, ktorá mi ju poskytla na študijné účely. Písomnú pozostalost', v ktorej sa Štefánik venuje otázkam slovenského pravopisu a pôvodu slovenčiny, možno vd’aka označeniu v záhlaví pracovne rozdelit' do niekol'kých celkov, pričom jeden z celkov má označenie „Poznámky o našom slovenskom pravopise, zvlášt' o y-ne" a strany v ňom sú aj číslované. Pri citovaní z tohto dokumentu uvádzam číslo strany.

16 Rukopisná pozostalost' I. B. Štefánika, strana 6.

17 Rukopisná pozostalost' I. B. Štefánika, strana 7.

18 Rukopisná pozostalost' I. B. Štefánika, strana 6. 
(Hurban 2014: 80). Bol presvedčený, že spisovný jazyk nemôže byt' založený na „labilnom pravidle“, ale musí mat' „hlboký základ v koreňoch jednej národnej reči a nemôže sa rovnat podl'a nahodilej výslovnosti ludí“ (Hurban 2014: 80). Presadzoval myšlienku, že pravopis musí zachytávat' len ustálenú a kodifikovanú podobu jazyka. Ortografické pravidlo „píš ako hovoríš, ktoré Štefánik povýšil na základný pravopisný princíp, považoval VHV za „labilné“ a nevhodné pri uplatňovaní v modernej slovenčine.

K myšlienke ozrejmovat' a vysvetl'ovat' lingvistické javy týkajúce sa slovenskej ortografie, morfológie, lexikológie, etymológie i dialektológie priviedla VHV nepochybne jazyková situácia domáceho obyvatel'stva a nedostatok odborných a normatívnych publikácií využívaných vo Vojvodine vo vyučovacom procese a vzdelávaní. Pozoroval, že najmä Slováci pracujúci vo verejných službách (kňazi, úradníci, pracovníci pošty, učitelia) neovládajú slovenský pravopis a ich slovenčina je plná nárečových prvkov a srbizmov. Velmi citlivo vnímal podobu slovenčiny nielen v každodennej komunikácii, ale najmä v publicistickom priestore a administratívnom styku, v úradných dokumentoch. Usiloval sa preto pôsobit' na autorov verejných jazykových prejavov, aby slovenčinu používali správne, aby ovládali gramatiku a ortografiu. $\mathrm{O}$,nápravu“ chýb v slovenčine medzi Slovákmi pôsobiacimi vo verejnej sfére sa VHV usiloval už v dvadsiatych rokoch, ked'začal s prvými jazykovými kurzami a publikoval prednášky o slovenskom pravopise. Aby boli jeho aktivity čo najúčinnejšie a mali čo najväčší dosah, dopíňal osvetlovanie gramatických javov aj stimulačnými až provokujúcimi výzvami: „Toto sú v krátkosti hlavné pravidlá pre písanie slovenčiny. Toto by mal každý Slovák mat' v malom prste a ked' toto nevie, nech sa neopováži chytit pierko do ruky, aby zhanobil našu drahú materčinu. Nech radšej povie: neviem písat ako by mal oflinkovat' slovenčinu, lebo písat'nie je čarbat'. V prvom rade majú o správne písanie dbat' učitelia a farári a potom naše časopisy“ (Hurban 2014: 22).

Pravopisné a gramatické chyby vo verejných komunikátoch a v mediálnej sfére považoval VHV za neprípustné, a to až do takej miery, že žiadal o anulovanie platnosti obsahu dokumentov, ak tieto neboli správne napísané. Napríklad v roku 1939 sa obrátil na Maticu slovenskú v Juhoslávii ako na najvyššiu slovenskú inštitúciu v Juhoslávii so žiadostou o vyhlásenie neplatnosti Zápisnice senioriálneho konventu banátskeho. V liste adresovanom tajomníkovi Matice upozorňoval VHV na problematické pasáže $\mathrm{v}$ zápisnici vydanej tlačou a žiadal predmetné vydanie vyhlásit' za neplatné. Až po opravení gramatických, sémantických a štylistických chýb možno dokument znova vydat', pretože Zápisnica v pôvodnej forme „pre množstvo chýb je posmech pre banátsky seniorát a hanba pre celý náš slovenský národ v Juhoslávii“. ${ }^{19}$ Takýmto vyhlásením sa VHV postavil nielen do pozície „editora“, ale vystúpil tiež ako neúprosný kritik verejného komunikátu, v ktorom našiel množstvo problematických miest (tlačové chyby, chyby v skratkách, interpunkcii a skladbe, pravopisné a štylistické chyby). Neskrýval rozhorčenie z jazykových nedôsledností, ktoré sa v Zápisnici vyskytujú, a svoj kritický postoj vysvetl'oval, či skôr „obhajoval“ (pred doktorom Michalom Topol'ským, vtedajším

19 Citované z listu datovaného 2. októbra 1939. Archív Slovenskej evanjelickej a. v. cirkvi v Starej Pazove, číslo RSK19391002/4853: List: VHV O jazyku a nárečí. Kr. Matica slovenská v Juhoslávii - chyby v zápisniciach - banátskeho seniorálneho konventu. 
tajomníkom Matice slovenskej v Juhoslávii, ktorému list adresoval) najmä vnútornou bolest'ou: „Takéto hračkárstvo s drahým naším materinským jazykom ma vel'mi zabolelo [...] ako ma to bolí, ked'naši l'udia myslia, že slovenský jazyk je akási handra, s ktorou môžu robit', čo chcú. Sú vo významných úradoch, ale nedržali za potrebné, aby vtedy, ked' úradne niečo na verejnost' dávajú, bolo to dôstojné.“20

Na používaní spisovnej slovenčiny vo verejnej komunikácii VHV nesmierne záležalo. Svedectvom sú jeho verejné jazykovedné vystúpenia, odborné práce venované súdobej podobe slovenčiny vo Vojvodine aj praktické jazykové kurzy. $\mathrm{V}$ čase, ked' sa spisovná slovenčina nielen upevňovala medzi Slovákmi žijúcimi d'aleko od materskej krajiny, ale sústredila sa na ňu aj ich vedecká pozornost', objavil sa na ,jazykovednom poli“ zanietený kňaz a už etablovaný dramatik a prozaik s ideou pozdvihovania a posilňovania povedomia Slovákov o materinskom jazyku. Jeho ciel'om bolo pomocou praktických školení (vyučovania), odborných textov a populárno-vednej publicistiky približovat' gramatiku a najnovšiu kodifikáciu spisovnej slovenčiny miestnemu jazykovému spoločenstvu a zabezpečit' uplatňovanie spisovnej slovenčiny v širokom meradle aj v praxi (v interpersonálnej i vo verejnej komunikácii). Do akej miery sa však evanjelickému kňazovi napokon podarilo aplikovat' gramatické normatívy do podoby enklávnej slovenčiny, sa dá zistit' až podrobným konfrontačným výskumom prostredníctvom komparácie komunikátov z medzivojnového obdobia a zo súčasnosti. Skúmanie jazykového plánovania v medzivojnovom období (na pozadí jazykovedných textov vojvodinských vzdelancov) môže slúžit' ako východiskový bod k poznaniu i vysvetleniu súčasnej podoby jazyka v enkláve. Jazykovedné práce V. Hurbana Vladimírova i analytické texty I. B. Štefánika venované slovenskému pravopisu možno vnímat' nielen ako zaujímavé svedectvo doby, ale tiež ako inšpiratívny prameň $\mathrm{k}$ dejinám slovenskej lingvistiky a stavu aj fungovaniu slovenčiny za hranicami materskej krajiny.

\section{Archívne pramene}

Rukopisná pozostalost' Igora Branislava Štefánika (52 strán rozličnej proveniencie) - poskytnutá historičkou Gabrielou Gubovou Červenou z Pivnice (Srbsko).

Rukopisná pozostalost' Vladimíra Hurbana Vladimírova - Archív Slovenskej evanjelickej a. v. cirkvi v Starej Pazove (Srbsko).

\section{Pramene}

ANDRIĆ, Josip, 1942. Slovačka slovnica. Zagreb: Izdanje Hrvatsko-slovačkog društva. ANDRIĆ, Josip, 2013. Slovačka slovnica. Zagreb: Kiklos. ISBN 978-953-56937-4-1.

CZAMBEL, Samo, 1902. Rukovät'spisovnej reči slovenskej. Turčiansky Sv. Martin: Kníhkupecko-nakladatel'ský spolok.

HURBAN, Vladimír Vladimírov, 1927. Sedem hodín o slovenskom pravopise. Národná jednota, roč. 8, č. 24 (16. 6. 1927), s. 2-3.

HURBAN, Vladimír Vladimírov [Zmok], 1930a. Borba za malicherné veci. Národná jednota, č. 92 , s. 3 .

HURBAN, Vladimír Vladimírov [Ďurko], 1930b. O tom pravopise. (Odpoved' na kurzívu). Národná jednota, č. 93, s. 2.

HURBAN, Vladimír Vladimírov [Zmok], 1930c. Borba za malicherné veci. (Skromná odpoved' p. Ďurkovi). Národná jednota, č. 94, s. 2.

20 Citované z listu datovaného 2. októbra 1939. Archív Slovenskej evanjelickej a. v. cirkvi v Starej Pazove, číslo RSK19391002/4853: List: VHV O jazyku a nárečí. Kr. Matica slovenská v Juhoslávii - chyby v zápisniciach - banátskeho seniorálneho konventu. 

malicherné veci. Národná jednota, č. 97, s. 2.

HURBAN, Vladimír Vladimírov [VHV], 2003. Vlastný životopis. Stará Pazova: Miestny odbor Matice slovenskej, Slovenský evanjelický a. v. cirkevný zbor.

HURBAN, Vladimír Vladimírov, 2014. Jazykovedné práce. Zostavila Anna Marićová. Báčsky Petrovec: Slovenské vydavatel'ské centrum. ISBN 978-86-7103-725-8.

\section{Literatúra}

BABIAK, Michal, 2011. Vladimír Hurban Vladimírov. In ŠTEFKO, Vladimír a kolektív. Dejiny slovenskej drámy 20. storočia. Bratislava: Divadelný ústav, s. 121-142. ISBN 978-80-89369-36-2.

CUPANOVÁ, Katarína, 2021a. Poetika a estetika modernizmu v dvoch komorných hrách Vladimíra Hurbana Vladimírova z prvého desat'ročia 20. storočia (Ked'sa schladí..., 1905; Boj, 1907). Slovenská literatúra, roč. 68, č. 5, s. 529-548. ISSN 0037-6973.

CUPANOVÁ, Katarína, 2021b. Vianoce ako dramatická situácia v slovenskej modernistickej dráme prvého desatročia 20. storočia (Vladimír Hurban Vladimírov, Vladimír Hurban Svetozárov). Slovenská literatúra, roč. 68, č. 2, s. 154-173. ISSN 0037-6973.

DUDOK, Miroslav, 1997. Stav slovenčiny v Juhoslávii a jej výskum. In ONDREJOVIČ, Slavomír - ŠIMKOVÁ, Mária, ed. Sociolinguistica Slovaca 3. Slovenčina na konci 20. storočia, jej normy a perspektívy. Bratislava: Veda, s. 203-209.

DUDOK, Miroslav, 2002. Pluricentrický vývin modernej slovenčiny. In Studia Academica Slovaca 31. Redaktor J. Mlacek. Bratislava: Stimul, s. 42-50. ISBN 80-88982-59-6.

DUDOK, Miroslav, 2008. Zachránený jazyk. State o enklávnej a diasporálnej slovenčine. Nadlak: Vydavatel'stvo Ivan Krasko. ISBN 978-973-1070-41-4.

DUDOK, Miroslav, 2010. O diasporálnej slovenčine. Jazykovedný časopis, roč. 61, č. 1, s. 65-70. ISSN 0021-5597.

DUDOK, Miroslav, 2013. Podoby slovenčiny vo svete. In Slovenčina vo svete. Súčasný stav a perspektivy. Zborník z medzinárodnej konferencie. Bratislava: Univerzita Komenského, s. 15-21. ISBN 978-80-223-3490-7.

GLOVŇA, Juraj, 2018. Stav vojvodinskej slovenčiny ako enklávneho jazyka. Slavica Slovaca, roč. 53, č. 3-4, s. 86-93. ISSN 0037-6787.

GUBOVÁ ČERVENÁ, Gabriela, 2017. Igor Branislav Štefánik a pravopis slovenského jazyka. In HODOLIČOVÁ, Jarmila, ed. 270 rokov dejín, literatúry a jazyka Slovákov vo Vojvodine. Nový Sad: Univerzita v Novom Sade, s. 46-50. ISBN 86-915-2553-3.

HUČKOVÁ, Dana, 2016. Dve state o modernom dramatickom umení (VHV, Ivan Lilge Lysecký). Slovenská literatúra, roč. 63, č. 6, s. 454-467. ISSN 0037-6973.

KORUNIAK, Samuel, 2020. Dejiny spisovnej slovenčiny v prostredí vojvodinských Slovákov v medzivojnovom období. Nový Sad: Ústav pre kultúru vojvodinských Slovákov - Báčsky Petrovec: Slovenské vydavatel'ské centrum. ISBN 978-86-87947-42-9.

MARIĆOVÁ, Anna, 2006. Slovenské nárečie Starej Pazovy. Nadlak: Ivan Krasko - Bratislava: ESA. ISBN 973-107-005-2.

MARIĆOVÁ, Anna, 2011. Ojazyku. Báčsky Petrovec: Slovenské vydavatel'ské centrum. ISBN 978-86-7103-365-7.

MYJAVCOVÁ, Mária, 2009. Slovenská jazyková ćitanka. O slovenskom jazyku vo Vojvodine. Báčsky Petrovec: Slovenské vydavatel'ské centrum. ISBN 978-86-7103-336-7.

MYJAVCOVÁ, Mária, 2015. O slovensko-srbskom bilingvizme vo Vojvodine. Báčsky Petrovec: Slovenské vydavatel'ské centrum. ISBN 86-710-3445-3.

PAŠTEKA, Július, 1990. Slovenská dramatika v epoche realizmu. Bratislava: Tatran. ISBN 80-222-0185-5.

SESAR, Dubravka, 2013. Slovački jezik u Andrićevoj slovnici. In ANDRIĆ, Josip. Slovačka slovnica. Zagreb: Kiklos, s. 193-197. ISBN 978-953-56937-4-1.

ŠKORVANKOVÁ, Eva, 2017. Slovenská menšina v dnešnej Vojvodine a jej vztah so Slovenským štátom. In HODOLIČOVÁ, Jarmila, ed. 270 rokov dejín, literatúry a jazyka Slovákov vo Vojvodine. Nový Sad: Univerzita v Novom Sade, Filozofická fakulta, s. 85-91. ISBN 86-915-2553-3.

VLADIMÍR Hurban Vladimírov - tvorca modernej slovenskej drámy. Zborníkspolku vojvodinských slovakistov 8-9, 1986-1987. Nový Sad: Spolok vojvodinských slovakistov.

\author{
Mgr. Juliana Beňová \\ externá doktorandka \\ Katedra slovanských filológií \\ Filozofická fakulta Univerzity \\ Komenského \\ Gondova 2 \\ 81102 Bratislava 1 \\ Slovenská republika \\ E-mail: julianabenova73@gmail.com
}

